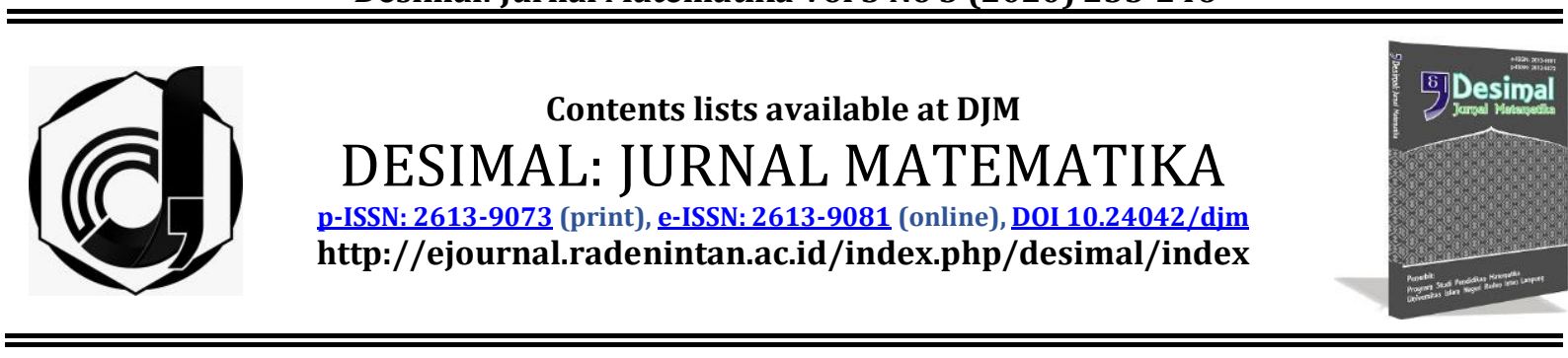

\title{
The Influence of Jigsaw-type Cooperative Learning Model on Students' Mathematics Learning Outcomes and Motivation
}

\author{
M. Amin*, Fitriani Nur, Mardhiah, Eka Damayanti, Suharti \\ Universitas Islam Negeri Alauddin Makassar, Indonesia;
}

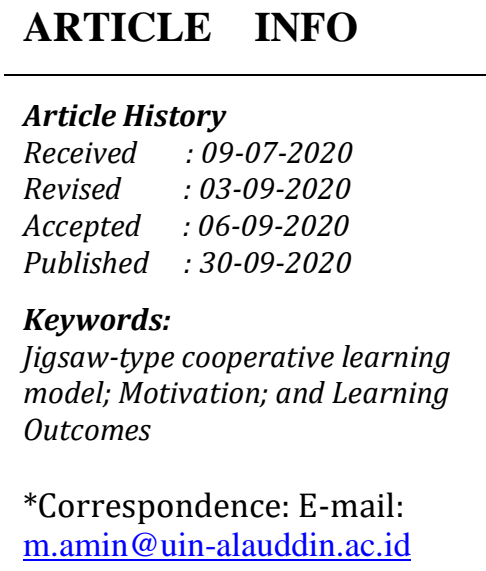

Doi:

$\underline{10.24042 / d j m . v 3 i 3.6831}$

\begin{abstract}
The learning process is inseparable from the learning model. The application of a learning model is an attempt to improve learning outcomes and learning motivation. This research aimed to determine the effect of the Jigsaw-type cooperative learning model on students' motivation and learning outcomes. This research was a quasi-experimental research with a non-equivalent control group design. The research instruments used were learning motivation questionnaires and tests. Data analysis techniques used were descriptive analysis and inferential analysis using the MANOVA test. The results showed that there was an influence of the Jigsawtype cooperative learning model on students' motivation and learning outcomes.
\end{abstract}

\section{INTRODUCTION}

Education is a conscious effort to achieve certain goals. A good education helps students to achieve the desired goals (Rosmaiyadi et al., 2018). The National Education System Law Number 20 of 2003 states that education is a conscious and planned effort to create an atmosphere of learning and the learning process so that students can actively develop their potential to have religious and spiritual strength, self-control, personality, intelligence, noble character, as well as the skills needed by himself, society, and the state (Suhana, 2014). One of the indicators of successful learning is the ability to attract students' attention. The learning activity is related to the process and effort did by teachers in delivering the learning materials to students through the material organization in the classroom (Irham \& Wiyani, 2013).

One of the learning materials in education is mathematics. Many students consider mathematics to be the most difficult learning material (Puspita \& Amalia, 2020). Students are less interested in mathematics (Prawiyogi et al., 2020). Those who think that mathematics is difficult will eventually understand it. It 
means that the action depends on the mind (Aslamiah \& Suparman, 2019). According to one of the mathematics teachers at MTs Ganrang Batu, students' learning motivation was lacking so that many students dislike mathematics and considered it difficult. Learning motivation is necessary for the learning process. It takes a variety of alternatives to generate students' motivation, including the application of learning models. According to Berlyana and Purwaningsih (2019), learning motivation can foster enthusiasm in learning so that students can be encouraged to carry out learning activities (Berlyana \& Purwaningsih, 2019). With motivation in the learning process, students will try to do any task and achieve the learning objectives (Sitohang et al., 2017). With learning motivation, students will be prepared to participate in learning activities. This is why the learning motivation variable was one of the data to be discovered in this research.

It is necessary to apply a learning model that can involve students actively in the learning process because the learning model used by the teacher greatly affects the learning outcomes that will be achieved by students (Akhmad, 2018). According to Janah and Subroto, cooperative learning is one of the teaching strategies designed to educate students to work together and interact within a group (Janah, I. \& Subroto, 2018). Cooperative learning is focused on motivating students to take an active role in interacting with other students in groups.

One of the cooperative learning models that can be used in problemsolving is the Jigsaw model. The Jigsaw model can support the development of students' problem-solving ability because they must learn within more specific small groups (Buhr et al., 2014). The Jigsaw-type cooperative learning model is slightly different from other cooperative learning models. According to Subiyantari, Muslim, and Rahmadyanti, students are grouped twice, when they are in their group and when they are in an expert group (Subiyantari et al., 2019). According to Djuli, the Jigsaw-type cooperative learning model contains learning activities that teachers need to provide, namely determining the learning objectives to be achieved, preparing the learning guidelines, forming heterogeneous groups, and presenting (Djuli, 2016). The Jigsaw-type cooperative learning model is one of the learning models that require students to help each other in building and understanding class assignments (Abed et al., 2019).

One of the factors that can affect students' learning outcomes is learning motivation (Kohar, 2017). The learning motivation is defined as the students' tendency to perceive academic activities as meaningful and useful so that they try to take the desired academic benefits (Ningsih et al., 2016). According to Supardi (2012), a strong learning motivation will encourage students to try hard and never give up when facing all challenges and obstacles while studying so that in the end, they will produce optimum learning achievement (Supardi, 2012). This is also reinforced by previous research which suggests that students' ability to understand mathematical concepts will increase by applying the Jigsaw-type cooperative learning model (Ananda et al., 2020; Septian \& Ramadhanty, 2020). According to Novitasari and Leonard (2017), there is a significant influence on students' ability to understand mathematical concepts on their mathematics learning outcomes (Novitasari \& Leonard, 2017). According to Sumarsih and Pardimin (2017), the Jigsaw-type cooperative learning model can increase students' understanding and learning motivation (Sumarsih \& Pardimin, 2017). The difference between this research and the previous ones was that this research simultaneously tested 
the effect of the Jigsaw-type cooperative learning model on students' motivation and mathematics learning outcomes. Various studies had been conducted on the relationship between learning models, learning outcomes, and learning motivation. The learning motivation which is usually used as the modifier variable in previous studies served as the dependent variable in this research.

\section{METHOD}

This research was a quasiexperimental research with the quantitative approach. The research design used was the non-equivalent control group design to determine the initial state and determine the difference between experimental groups I and II. The pretest results are considered good if the experimental class scores are not significantly different. This research was conducted at MTs Ganrang Batu which is located at Ganrang Batu Selatan of Kayuloe Timur Village, Turatea District, Jeneponto Regency. The seventh-grade students of MTs Ganrang Batu in the $2018 / 2019$ academic year were involved in this research. The students were divided into 2 classes, namely class A and class B which consisted of 40 students. The sampling technique used was the saturated sampling technique so that from the 2 classes, one of them was taken as the control class and the other one was taken as the experimental class. The data collection techniques were written tests and questionnaires to determine student motivation and learning outcomes. The indicators of learning motivation were the willingness and desire to succeed, encouragement and need in learning, future hopes and aspirations, appreciation in learning, interesting activities in learning, and a conducive learning environment that allowed students to learn better (Uno, 2016). The data analysis technique in this research was the descriptive analysis and inferential analysis with prerequisite tests, namely the normality test, the homogeneity test, and the hypothesis test using the MANOVA test.

\section{RESULTS AND DISCUSSION}

The results indicated that there was a difference in the students' average learning motivation between the experimental class and the control class. The average learning motivation of the class that applied the Jigsaw-type cooperative learning model (78.05) was higher than the class that did not apply the Jigsaw-type cooperative learning model (51.70). the detail can be seen in table 1 .

Table 1. The Description of Learning Motivation in the Experiment Class and the Control Class

\begin{tabular}{lrcc}
\hline \multicolumn{1}{c}{ Class } & N & Mean & $\begin{array}{c}\text { Std. } \\
\text { Deviation }\end{array}$ \\
Experimental & 20 & 78.05 & 8,281 \\
Control & 20 & 51.70 & 5,090 \\
\hline
\end{tabular}

The mean difference was in line with the percentage of learning motivation categories between the experimental class and the control class which also different. The learning motivation of students who were taught using the Jigsaw-type cooperative learning model was in the high category while the learning motivation of students who were not taught using the Jigsaw-type cooperative learning model was in a low category. The details of learning motivation categories can be seen in table 2. 
Desimal, 3 (3), 2020 - 238

M. Amin, Fitriani Nur, Mardhiah, Eka Damayanti, Suharti

Table 2. The Categories of Learning Motivation in the Experiment Class and the Control Class

\begin{tabular}{llcccc}
\hline Interval & Categories & \multicolumn{2}{c}{$\begin{array}{c}\text { The Learning Motivation } \\
\text { of the Experimental Class }\end{array}$} & $\begin{array}{r}\text { The Learning Motivation of } \\
\text { the Control Class } \\
\text { P (\%) }\end{array}$ \\
\hline $20-36$ & Poor & 0 & 0 & 0 & 0 \\
$37-52$ & Low & 1 & 5 & 13 & 65 \\
$53-68$ & Moderate & 2 & 10 & 7 & 35 \\
$69-84$ & High & 12 & 60 & 0 & 0 \\
$85-100$ & Excellent & 5 & 35 & 0 & 0 \\
Total & & 20 & 100 & 20 & 100 \\
\hline
\end{tabular}

The results of the descriptive analysis showed that there were differences in the mean scores and the students' learning motivation categories. The class that was taught using the Jigsawtype cooperative learning model had a high level of learning motivation. The results of the descriptive analysis were in line with the results of the MANOVA test with the p-value of $0.04<0.05$ which indicated that $\mathrm{H}_{0}$ was rejected. It meant that there was an effect of the Jigsaw-type cooperative learning model on the learning motivation of the seventh-grade students of MTs Ganrang Batu.

The results of the analysis were relevant with the advantages of the Jigsaw-type cooperative learning model which can stimulate students' learning motivation and can make it easier for them to remember an event (Suprihatin, 2017). The Jigsaw-type cooperative learning model can maximize the students' activeness in the learning process by collecting information, discussing, and helping each other in learning mathematical concepts so that their conceptual understanding could be improved (Istihapsari, 2017). The results are also relevant to the research conducted by Wicaksono (2018) that there is an effect of the Jigsaw-type cooperative learning model on students' learning motivation (Wicaksono, 2018).

These results are in line with the research by Asnawi, Ikhsan, and Hajidin
(2020), which concluded that there are differences in learning motivation between students who are taught using the Jigsaw-type cooperative learning model and students who are taught using the STAD learning model (Asnawi et al., 2020). According to Utomo (2016), motivation can make students learn by using higher cognitive processes so that they can better absorb and remember the learning material (Utomo, 2016).

Research by Tarigan (2014), concluded that the use of the Jigsaw-type cooperative learning model can increase students' learning motivation in mathematics (Tarigan, 2014). I am also in line with the research by Batubara (2018) which states that the Jigsaw-type cooperative learning model, students' learning motivation in mathematics increases (Batubara, 2018).

Research by Anggis (2017) concluded that the application of the Jigsaw-type cooperative learning model can increase learning motivation (Anggis, 2017). It is similar to the research by Kesuma and Sukirno (2016) where students' learning motivation increased after implementing the Jigsaw-type cooperative learning model (Kesuma \& Sukirno, 2016). Likewise, the research by Susanto, Handayani, Akhlis (2013) concluded that the application of the Jigsaw II cooperative learning model can increase students' learning motivation (Susanto et al., 2013). 
According to Cleopatra (2015), motivation is a factor that stimulates a person in the form of an urge to act and behave (Cleopatra, 2015). Two factors influence a person to be motivated in learning (Anggraini, 2016), The first is the internal factors that come from within a person. Someone will acknowledge the importance of learning that can affect the present and future life so that the motivation will be formed. The second is the external factors that come from outside a person or commonly known as environmental factors. The involvement of other people or the environment can provide a stimulus.

The average mathematics learning outcomes between the experimental class and the control class was different. The average learning outcomes of the experimental class that applied the Jigsaw-type cooperative learning model was 67.35 which was higher than the class that did not apply the Jigsaw-type cooperative learning model (58.05). The detail can be seen in table 3 .

Table 3. The Posttest Learning Outcomes of the Experiment Class and Control Class

\begin{tabular}{cccc} 
Class & N & Mean & $\begin{array}{c}\text { Std. } \\
\text { Deviation }\end{array}$ \\
Experimental & 20 & 67.35 & 19,693 \\
Control & 20 & 58.05 & 15,555 \\
\hline
\end{tabular}

The mean difference was in line with the learning outcome percentage of the experimental class that applied the Jigsaw-type cooperative learning model. The detail can be seen in Table 4 .

Table 4. The Categories of Mathematics Learning Outcomes of the Experimental Class and Control Class

\begin{tabular}{|c|c|c|c|c|c|}
\hline \multirow[t]{2}{*}{ Interval } & \multirow[t]{2}{*}{ Category } & \multicolumn{2}{|c|}{$\begin{array}{c}\text { Experimental Class } \\
\text { posttest }\end{array}$} & \multicolumn{2}{|c|}{$\begin{array}{c}\text { Control Class } \\
\text { posttest }\end{array}$} \\
\hline & & $\mathbf{F}$ & P (\%) & $\mathbf{F}$ & P (\%) \\
\hline $0-20$ & Poor & 0 & 0 & 0 & 0 \\
\hline $21-40$ & Low & 3 & 15 & 2 & 10 \\
\hline $41-60$ & Moderate & 3 & 15 & 10 & 50 \\
\hline $61-80$ & High & 8 & 40 & 7 & 35 \\
\hline $81-100$ & Excellent & 6 & 30 & 1 & 5 \\
\hline \multicolumn{2}{|c|}{ total } & 20 & 100 & 20 & 100 \\
\hline
\end{tabular}

Table 4 shows that the excellent category of the learning outcome in the experimental class was at $30 \%$ while the control class was only at $5 \%$. This showed that the two classes, namely the experimental class and the control class, achieved different results as a result of the treatment carried out by the researcher.

The results of the descriptive analysis were also in line with the MANOVA test with the $\mathrm{p}$-value $=0.0001$ $<0.05$, so $H_{0}$ was rejected. The results indicated that the Jigsaw-type cooperative learning model influenced the mathematics learning outcomes of the seventh-grade students of MTs Ganrang Batu. The results were reinforced by
Gulsen CaGaTay (2013) which discovers that the experimental group students who were taught with the Jigsaw learning obtained much better learning outcomes than the control group students who were taught using the conventional model (Gulsen CaGaTay, 2013).

The results of this research are in line with the research by Andini and Barutu (2019) which states that there was a significant influence of the Jigsaw-type cooperative learning model on students' learning outcomes (Andini \& Barutu, 2019). Likewise, research by Dinar, Asdar, and Saputri (2018) discovers that the mathematics learning outcomes of students who were taught using a Jigsaw- 
type cooperative learning model were higher than students who were taught using STAD cooperative learning model (Dinar et al., 2018).

Rosyidah (2016) concludes that the Jigsaw-type cooperative learning model had a positive influence on students' learning outcomes (Rosyidah, 2016). It is also similar to the research results by Singga (2011) that there is a significant difference in the mathematics learning outcomes between the application of the Jigsaw-type cooperative learning model and the application of the conventional learning model (Singga, 2011).

Basuki (2015) states that the use of the Jigsaw-type cooperative learning model in learning can activate students' activities and can improve their learning outcomes (Basuki, 2015). A similar result was also found in research by Hia (2013), that after applying the Jigsaw-type cooperative learning model, there was an increase in students' activity and learning outcomes (Hia, 2013). Nasruddin and Abidin (2017) state that students' mathematics learning outcomes were improved after implementing the Jigsawtype cooperative learning model (Nasruddin \& Abidin, 2017).

According to Lestari (2015), learning outcomes change after carrying out the learning process. Changes in psychomotor, affective, and cognitive aspects are a form of change as a result of the learning process (Lestari, 2015). In assessing students' learning outcomes, Subagia and Wiratma (2016) state that it depends on what competencies will be assessed. To assess the students' attitudes, an assessment can be carried out through observation, self-assessment, and peer assessment (Subagia \& Wiratma, 2016). To assess the knowledge, the assessments can be written tests, oral tests, and assignments. Skills competency assessment can be done through performance appraisals such as portfolios, projects, and practical assessments.
According to Slameto in Suwardi (2012), two factors influence a person's success in the learning process, namely (a) internal factors or often referred to as factors that come from within a person which include physical factors, psychological factors, and student activeness in society; (b) external factors or factors that come from outside a person are usually called environmental factors, including family factors (upbringing from parents, relationships among family members, family economic conditions, understanding of parents and cultural background), school factors (learning methods, tools, materials, media, curriculum, learning standards, the state of the school environment, school facilities and infrastructure, relationships between teachers and students, and the relationships between students and other students (Suwardi, 2012).

The separate test results showed that the Jigsaw-type cooperative learning model influenced students' learning motivation. Likewise, the Jigsaw-type cooperative learning model influenced students' learning outcomes. To test both factors, the MANOVA test was carried out. The statistical tests used were the Pillai's Trace test, Wilks' Lambda, Hotelling's Trace, Roy's Largest Root contained in the Multivariate Test table.

Table 5. Multivariate Significance Tests

\begin{tabular}{lllll}
\hline Effect & & Value & F & Sig. \\
Class & Pillai's & .079 & $1.595 \mathrm{~b}$ & .005 \\
& Trace & & & \\
& $\begin{array}{l}\text { Wilks' } \\
\text { Lambda }\end{array}$ & .921 & $1.595 \mathrm{~b}$ & .005 \\
& $\begin{array}{l} \\
\text { Hotelling' } \\
\text { s Trace }\end{array}$ & .086 & $1.595 \mathrm{~b}$ & .005 \\
& & & \\
& $\begin{array}{l}\text { Roy's } \\
\text { Largest } \\
\text { Root }\end{array}$ & .086 & $1.595 \mathrm{~b}$ & .005 \\
& & & \\
\hline
\end{tabular}

The multivariate test results showed that the p-values for Pillai's Trace, Wilks Lambda, Hotelling's Trace, Roy's Largest Root were $0.005<0.05$. since the F values of the Pillai's Trace, Wilks Lambda, 
Hotelling's Trace, Roy's Largest Root were all significant, so $\mathrm{H}_{\mathrm{o}}$ was rejected. This indicated that there is an influence of the Jigsaw-type cooperative learning model on learning motivation and mathematics learning outcomes.

The results of this research were supported by Yemi, Binti, and Azid (2018) who stated that the learning achievement of the experimental group who were taught using the Jigsaw-type cooperative learning model was better than students who were taught using the lecture method (Yemi et al., 2018). Also, Lasmawan and Sutama (2013), states that there are differences in motivation and learning outcomes between groups of students who are taught using the jigsaw-type cooperative learning model and groups of students who are taught using the conventional learning model (Lasmawan \& Sutama, 2013). In other research, Jaya (2016) concludes that there is an influence of the Jigsaw-type cooperative learning model on students' Geography learning outcomes so that this model can be used to improve students' learning outcomes (Jaya, 2016).

Research by Juwaeriah, Muhyani, and Ikhtiono (2017) conclude that there is a significant influence between motivation and students' learning outcomes between the Jigsaw-type cooperative learning model and the conventional learning model (Juwaeriah et al., 2017). Sudharmini, Lasmawan, and Natajaya (2014) state that there are differences in students' learning motivation and learning outcomes between students who were taught using the Jigsaw-type cooperative learning model and students who were taught using the conventional learning model (Sudharmini et al., 2014).

Sumarsih and Pardimin (2017) conclude that there is an increase in students' learning motivation and students' learning outcomes after implementing the Jigsaw-type cooperative learning model (Sumarsih \& Pardimin,
2017). Likewise, the research by Sulasmi, Lasmawan, and Landrawan (2013) discovers that after implementing the Jigsaw-type cooperative learning model, there was an increase in students' learning motivation and learning outcomes (Sulasmi et al., 2013). Kesnajaya, Dantes, \& Dantes (2015) state that to improve students' motivation and learning achievement, the application of the Jigsaw-type cooperative learning model is quite effective to be used.

One of the factors that affect learning outcomes is students' learning motivation. According to Emda (2017), the learning success of students is greatly influenced by the presence or absence of motivation in learning (Emda, 2017). If there are a desire and encouragement to learn, learning success can be achieved. Hamdu and Agustina (2011) state that students who have high learning motivation will also get high learning outcomes because students with high motivation will study harder, more persistent, and more diligent so that it will affect their learning outcomes (Hamdu \& Agustina, 2011). Mulyaningsih (2014) states that the students' learning success is due to the high motivation they possess (Mulyaningsih, 2014). To improve learning outcomes, someone who has high learning motivation will try to be more active, persistent, never give up, and study hard. Therefore, in the learning process, it is necessary to pay attention to the treatment given to students so that learning motivation and learning outcomes can increase. The information as the results of this research provides an overview of the effect of the learning model.

\section{CONCLUSIONS AND SUGGESTIONS}

It can be concluded that there was a significant effect of the application of the Jigsaw-type cooperative learning model on students' learning outcomes and motivation. 
Future research can develop and retry with different learning models that can better influence students' learning motivation. The jigsaw learning model can also be investigated whether it can affect students' abilities in other aspects of ability.

\section{REFERENCES}

Abed, A. Z., Sameer, S. A., Kasim, M. A., \& Othman, A. T. (2019). Predicting effect implementing the jigsaw strategy on the academic achievement of students in mathematics classes. International Electronic Journal of Mathematics Education, 15(1).

Akhmad, H. (2018). Pengaruh model pembelajaran terhadap hasil belajar matematika ditinjau dari motivasi belajar siswa. Universitas Negeri Makassar.

Ananda, M. I., Makmuri, \& Hakim, L. El. (2020). Upaya meningkatkan kemampuan pemahaman konsep matematika siswa dengan model pembelajaran jigsaw berbantuan Geogebra di kelas XI IPS 1 SMA Diponegoro 1 Jakarta. Jurnal Riset Pembelajaran Matematika Sekolah, 4(1), 20-29. https://doi.org/10.21009/JRPMS.20 20.0706

Andini, M., \& Barutu, F. A. (2019). Pengaruh model pembelajaran kooperatif tipe jigsaw terhadap hasil belajar matematika siswa kelas VIII SMP Negeri 3 Tebing Tinggi Kabupaten Kepulauan Meranti. Jurnal Online Mahasiswa: Pendidikan Matematika, 1(2), 65-79.

Anggis, E. V. (2017). Penerapan model kooperatif jigsaw berbasis lesson study untuk meningkatkan motivasi belajar. Gema Wiralodra, 8(1), 83-88.

Anggraini, I. S. (2016). Motivasi belajar dan faktor-faktor yang berpengaruh: sebuah kajian pada interaksi pembelajaran mahasiswa. Formatif: Jurnal Ilmiah Pendidikan MIPA, 1(2), 168-181.

Aslamiah, \& Suparman. (2019). Analisis kebutuhan media interaktif matematika berbasis android untuk menstimulus berpikir kritis siswa.
Science, Technology, Engineering, Economics, Education and Mathematics, 1(1), 178-184.

Asnawi, Ikhsan, M., \& Hajidin. (2020). Pengaruh model kooperatif tipe student teams achievement division dan tipe jigsaw terhadap prestasi dan motivasi belajar siswa SMP. Numeracy Journal, 7(1), 150-162. https://doi.org/https://doi.org/10.4 6244/numeracy.v7i1.1039

Basuki, N. (2015). Peningkatan aktivitas dan hasil belajar siswa menggunakan model pembelajaran kooperatif tipe jigsaw pada mata pelajaran matematika siswa kelas VII SMPN 2 Bumiratu Nuban tahun pelajaran 2014/2015. AKSIOMA: Jurnal Program Studi Pendidikan Matematika, 4(1), 78-91.

Batubara, E. (2018). Penerapan model pembelajaran kooperatif tipe jigsaw untuk meningkatkan motivasi belajar siswa pada pelajaran matematika kelas V SD Negeri 104204 Sambirejo Timur. Elementary School Journal PGSD FIP UNIMED, 8(1), 1-8.

Berlyana, M. D. P., \& Purwaningsih, Y. (2019). Experimentation of STAD and jigsaw learning models on learning achievements in terms of learning motivation. International Journal of Educational Research Review, 4(4), 517-524. https://doi.org/10.24331/ijere.6283 11

Buhr, G. T., Heflin, M. T., White, H. K., \& Pinheiro, S. O. (2014). Using the jigsaw cooperative learning method to teach medical students about longterm and postacute care. Journal of the American Medical Directors Association, 15(6).

Cleopatra, M. (2015). Pengaruh gaya hidup dan motivasi belajar terhadap prestasi belajar matematika. Formatif: Jurnal Ilmiah Pendidikan MIPA, 5(2).

Dinar, M., Asdar, \& Saputri, S. A. (2018). Pengaruh penerapan model pembelajaran kooperatif terhadap hasil belajar matematika siswa ditinjau dari motivasi belajar siswa (penelitian eksperimen penerapan model pembelajaran kooperatif tipe jigsaw dan STAD). Issues in Mathematics Education, 2(1), 11-22.

Djuli, L. (2016). Effect of method method 
versus jigsaw teams- student achievement divisions ( STAD ) and style cognitive learning outcomes of discourse reading comprehension grade SMPN 10 Kota Kupang. International Conference on Education, 499-507.

Emda, A. (2017). Kedudukan motivasi belajar siswa dalam pembelajaran. Lantanida Journal, 5(2), 93-196. https://doi.org/10.22373/lj.v5i2.28 38

Gulsen CaGaTay, G. (2013). The effect of jigsaw-i cooperative learning technique on students understanding about basic organic. International Journal of Educational Researchers, 4(230-37).

Hamdu, G., \& Agustina, L. (2011). Pengaruh motivasi belajar terhadap prestasi belajar IPA di sekolah dasar. Jurnal Penelitian Pendidikan, 12(1), 81-86.

Hia, Y. (2013). Penerapan model pembelajaran kooperatif tipe jigsaw untuk meningkatkan aktivitas dan hasil belajar matematika siswa kelas VIII. Generasi Kampus, 6(2), 51-62.

Irham, M., \& Wiyani, N. A. (2013). Psikologi pendidikan teori dan aplikasi dalam proses pembelajaran. Ar-Ruzz Media.

Istihapsari, V. (2017). Meningkatkan pemahaman konsep materi matematika SMP menggunakan model pembelajaran kooperatif tipe jigsaw pada mahasiswa prodi pendidikan matematika UAD. AdMathEdu, 7(1), 83-98.

Janah, I., I., \& Subroto, W. (2018). Comparison of cooperative learning models with inquiry on student learning outcomes. International Journal of Educational Research Review, 4(2).

Jaya, E. P. (2016). Pengaruh model pembelajaran kooperatif tipe jigsaw terhadap hasil belajar geografi siswa kelas XI IPS SMA Negeri 1 Tulang Bawang Tengah tahun pelajaran 2015/2016. In Fakultas Keguruan dan Ilmu Pendidikan. Universitas Lampung.

Juwaeriah, S., Muhyani, \& Ikhtiono, G. (2017). Pengaruh model pembelajaran kooperatif tipe jigsaw terhadap motivasi belajar dan hasil belajar siswa pada mata pelajaran matematika. Attadib Journal of
Elementary Education, 1(2), 78-93.

Kesnajaya, I. K., Dantes, N., \& Dantes, G. R. (2015). Pengaruh model pembelajaran kooperatif tipe jigsaw terhadap motivasi belajar dan hasil belajar IPA siswa kelas $\mathrm{V}$ pada SD Negeri 3 Tianyar Barat. Jurnal Pendidikan Dasar Ganesha, 5(1), 1-9.

Kesuma, M. A. I., \& Sukirno. (2016). Implementasi model pembelajaran kooperatif teknik jigsaw untuk meningkatkan motivasi belajar akuntansi siswa. Journal of Accounting and Business Education, 2(3), 1-11.

Kohar, N. M. (2017). Pengaruh LMS edmodo terhadap motivasi dan hasil belajar biologi peserta didik SMP Negeri 3 Wonomulyo. In Eprints. Universitas Negeri Makassar.

Lasmawan, I. W., \& Sutama, I. M. (2013). Pengaruh pembelajaran kooperatif tipe jigsaw terhadap motivasi dan hasil belajar IPS kelas VIII Mts Nw Gereneng Kecamatan Sakra Timur NTB tahun pelajaran 2011/2012. PENDASI: Jurnal Pendidikan Dasar Indonesia, 3(1).

Lestari, I. (2015). Pengaruh waktu belajar dan minat belajar terhadap hasil belajar matematika. Formatif: Jurnal Ilmiah Pendidikan MIPA, 3(2), 115125.

https://doi.org/doi.org/10.30998/fo rmatif.v3i2.118

Mulyaningsih, I. E. (2014). Pengaruh interaksi sosial keluarga, motivasi belajar, dan kemandirian belajar terhadap prestasi belajar. Jurnal Pendidikan Dan Kebudayaan, 20(4), 441-451.

Nasruddin, \& Abidin, Z. (2017). Meningkatkan hasil belajar matematika melalui model pembelajaran kooperatif tipe jigsaw pada siswa SMP. Journal of Educational Science and Technology (EST), 3(2), 113-121.

Ningsih, A., Azis, A. A., \& Ngitung, R. (2016). Perbandingan motivasi dan hasil belajar peserta didik melalui penerapan model pembelajaran inkuiri terstruktur dan model pembelajaran inkuiri terbimbing pada materi fungi. Universitas Negeri Makassar.

Novitasari, L., \& Leonard. (2017). Pengaruh kemampuan pemahaman 
konsep matematika terhadap hasil belajar matematika. Prosiding Diskusi Panel Nasional Pendidikan Matematika., 3, 758-766.

Prawiyogi, A. G., Sri Wulan Anggraeni, \& Rahayu, T. G. (2020). Penerapan model creative problem solving (CPS) untuk meningkatkan kemampuan berpikir kreatif matematis siswa sekolah dasar. Jurnal Basicedu, 4(1). https://doi.org/https://doi.org/10.3 1004/basicedu.v4i1.295

Puspita, D., \& Amalia, R. (2020). Koordinasi bimbingan konseling dengan guru bidang matematika. Jurnal Pendidikan Dan Konseling, 1(2), 1-7. https://doi.org/https://doi.org/10.3 1004/jpdk.v1i2.528

Rosmaiyadi, R., Mariyam, M., \& Juliyanti, J. (2018). Pemahaman konsep matematis siswa dengan strategi pembelajaran group to gruop exchange berpendekatan kontekstual. Jurnal Penelitian Dan Pembelajaran Matematika, 11(1). https://doi.org/10.30870/jppm.v11i 1.2993

Rosyidah, U. (2016). Pengaruh model pembelajaran kooperatif tipe jigsaw terhadap hasil belajar matematika siswa kelas VIII SMP Negeri 6 Metro. Jurnal SAP (Susunan Artikel Pendidikan), 1(2), 115-124. https://doi.org/10.30998/sap.v1i2.1 018

Septian, A., \& Ramadhanty, C. L. (2020). Peningkatan pemahaman konsep matematika siswa SMP melalui model pembelajaran kooperatif tipe jigsaw. WACANA AKADEMIKA: Majalah Ilmiah Kependidikan, 4(1), 56. https://doi.org/10.30738/wa.v4i1.7 782

Singga, L. (2011). Pengaruh model pembelajaran kooperatif tipe jigsaw dan TSTS terhadap hasil belajar matematika. Jurnal Pendidikan Matematika, 2(1), 55-64.

Sitohang, S., Setiawan, D., \& Dewi, R. (2017). Students' motivation in using jigsaw strategy on civics education of the class VII students of SMP TD Pardede Foundation Sunggal in 2016/2017, Medan, Indonesia. International Journal of Education, Learning and Development, 5(8), 3034.
Subagia, I. W., \& Wiratma, I. G. L. (2016). Profil penilaian hasil belajar siswa berdasarkan kurikulum 2013. Jurnal Pendidikan Indonesia, 5(1), 39-54.

Subiyantari, A. R., Muslim, S., \& Rahmadyanti, E. (2019). Effectiveness of jigsaw cooperative learning models in lessons of the basics of building construction on students learning 'outcomes viewed from critical thinking skills. International Journal for Educational and Vocational Studies, 1(7), 691696.

https://doi.org/10.29103/ijevs.v1i7. 1653

Sudharmini, L. S., Lasmawan, I. W., \& Natajaya, I. N. (2014). Pengaruh model pembelajaran kooperatif tipe jigsaw terhadap motivasi belajar dan hasil belajar IPS siswa kelas V Sekolah Dasar Gugus IV Jimbaran, Kuta Selatan. Jurnal Pendidikan Dasar Ganesha, 4(1), 1-10.

Suhana, C. (2014). Konsep strategi pembelajaran. PT. Rafika Aditama.

Sulasmi, N. M., Lasmawan, I. W., \& Landrawan, I. W. (2013). Penerapan model pembelajaran kooperatif tipe jigsaw untuk meningkatkan motivasi dan hasil belajar siswa pada mata pelajaran PKn di kelas X 2 SMA Negeri 2 Banjar tahun ajaran 2012/2013. Jurnal Pendidikan Kewarganegaraan Undiksha, 2(1), 1-12.

Sumarsih, \& Pardimin. (2017). Upaya peningkatan motivasi dan prestasi belajar IPA melalui penerapan model pembelajaran jigsaw pada siswa kelas IX B SMPN 9 Yogyakarta. WIYATA DHARMA: Jurnal Penelitian Dan Evaluasi Pendidikan, 5(2), 123134.

https://doi.org/http://dx.doi.org/10 .30738/wd.v5i2.3379

Supardi. (2012). Pengaruh pembelajaran matematika realistik terhadap hasil belajar matematika ditinjau dari motivasi belajar. Cakrawala Pendidikan, 2, 244-255. https://doi.org/https://doi.org/10.2 1831/cp.v5i2.1560

Suprihatin, S. (2017). Pengaruh model pembelajaran jigsaw terhadap hasil belajar study masyarakat indonesia mahasiswa. Jurnal Promosi, 5(1).

Susanto, Handayani, L., \& Akhlis, I. (2013). Penerapan model pembelajaran 
Desimal, 3 (3), 2020 - 245

M. Amin, Fitriani Nur, Mardhiah, Eka Damayanti, Suharti

kooperatif tipe jigsaw II untuk meningkatkan motivasi belajar siswa kelas VIIIA Mts NU Ungaran. Unnes Physics Education Journal, 2(1), 2026.

Suwardi, D. R. (2012). Faktor-faktor yang mempengaruhi hasil belajar siswa kompetensi dasar ayat jurnal penyesuaian mata pelajaran akuntansi kelas XI IPS di SMA Negeri 1 Bae Kudus. Economic Education Analysis Journal, 1(2), 1-7.

Tarigan, D. (2014). Penerapan model pembelajaran kooperatif tipe jigsaw untuk meningkatkan motivasi belajar siswa pada pelajaran matematika kelas V SD Negeri 101774 Sampali. Elementary School Journal PGSD FIP UNIMED, 1(2), 94-102.

Uno, B. H. (2016). Teori motivasi dan pengukurannya analisis di bidang pendidikan. PT. Bumi Aksara.

Utomo, M. (2016). Penerapan metode discovery untuk meningkatkan motivasi belajar siswa kelas X mata pelajaran biologi materi jamur di SMA Negeri 3 Simpang Hilir Kabupaten Kayong Utara tahun pelajaran 2015/2016. Jurnal Visi Ilmu Pendidikan, $\quad 7(3)$. https://doi.org/10.26418/jvip.v7i3. 17185

Wicaksono, D. (2018). Pengaruh model pembelajaran kooperatif tipe jigsaw terhadap motivasi belajar siswa dalam mata pelajaran ilmu pengetahuan alam (IPA) di kelas IVB Sekolah Dasar Negeri Joglo No.76 Kota Surakarta tahun ajaran 2015/2016. Karya Ilmiah Mahasiswa Progdi Pendidikan Guru Sekolah Dasar FKIP, 1(2).

Yemi, T. M., Binti, N., \& Azid, H. (2018). Effect of jigsaw strategy of cooperative learning on mathematics achievement among secondary school students. European Journal of Education Studies, 4(1). 
Desimal, 3 (3), 2020 - 246

M. Amin, Fitriani Nur, Mardhiah, Eka Damayanti, Suharti 